\title{
CARROT YIELD AND RECOVERY EFFICIENCY OF NITROGEN, PHOSPHORUS AND POTASSIUM ${ }^{1}$
}

\author{
NATÁLIA SILVA ASSUNÇÃO ${ }^{2}$, JUNIA MARIA CLEMENTE ${ }^{3}$, LEONARDO ANGELO DE AQUINO ${ }^{2 *}$, LUCIEL \\ RAUNI DEZORDI ${ }^{4}$, LUIZ PAULO DORNELAS DOS SANTOS ${ }^{2}$
}

\begin{abstract}
The objective of this work was to evaluate the carrot crop recovery efficiency of nitrogen, phosphorus and potassium from fertilizers. Two experiments were conducted in an experimental area in Rio Paranaiba - MG. The cultivar ('Juliana') was sown during the summer period and the cultivar 'Nayarit' during the winter period. In both experiments, the treatments consisted of six fertilization combinations of $\mathrm{N}, \mathrm{P}_{2} \mathrm{O}$, $\mathrm{K}_{2} \mathrm{O}\left(\mathrm{kg} \mathrm{ha}^{-1}\right)$ : fertilization without $\mathrm{N}(0-500-450)$, without $\mathrm{P}(100-0-450)$, without $\mathrm{K}(100-500-0)$, standard (100-500-450), higher than standard (100-700-600) and lower than standard (100-300-300). The harvest was carried out when most of the roots presented commercial standard well accepted by the consumers. The fresh and dry matter of roots and leaves were quantified, and the yield was calculated based on the fresh matter. The analysis of $\mathrm{N}, \mathrm{P}$ and $\mathrm{K}$ contents in leaves and roots were carried out by harvest time, and the nutrients absorption and exportation were determined based on these contents and on the dry matter of roots and leaves. N, P and K omissions reduced the yield of the cultivar 'Juliana'. For the cultivar 'Nayarit', only P omission reduced and $\mathrm{P}$ and $\mathrm{K}$ fertilizations increased the yield. The cultivar 'Nayarity', which is more productive than 'Juliana", absorbed more quantities of N, P and K. Carrot recovery efficiency of nitrogen, phosphorus and potassium is low.
\end{abstract}

Keywords: Daucus carota. Fertilization. Extraction.

\section{PRODUTIVIDADE E EFICIÊNCIA DE RECUPERAÇÃO PELA CENOURA DE NITROGÊNIO, FÓSFORO E POTÁSSIO}

RESUMO - Objetivou-se com este trabalho avaliar a eficiência de recuperação de nitrogênio (N), fósforo (P) e potássio (K) pela cultura da cenoura. Foram implantados dois experimentos em área de cultivo localizada em Rio Paranaíba - MG. A cultivar "Juliana" foi semeada no período de verão e a cultivar "Nayarit" no período do inverno. Os tratamentos consistiram de seis combinações de fertilizações $\mathrm{N}_{-} \mathrm{P}_{2} \mathrm{O}_{5}-\mathrm{K}_{2} \mathrm{O}\left(\mathrm{kg} \mathrm{ha}{ }^{-1}\right)$ : sem N (0-500450), sem P (100-0-450), sem K (100-500-0), padrão (100-500-450), maior que o padrão (100-700-600) e menor que a padrão (100-300-300). A colheita foi realizada quando a maior parte das raízes apresentavam-se dentro do padrão comercial mais aceito pelos consumidores. Quantificaram-se as matérias fresca e seca das raízes e das folhas e com base na matéria fresca de raízes calculou-se a produtividade. Determinaram-se os teores de $\mathrm{N}, \mathrm{P}$ e K em folhas e raízes por ocasião da colheita e com bases nesses teores e na matéria seca de raízes e de folhas determinaram-se a absorção e a exportação de nutrientes. As fertilizações testadas influenciaram a produtividade comercial de ambas as cultivares. A omissão da fertilização com N, com P ou com K reduziu a produtividade da cultivar "Juliana". Para a cultivar "Nayarit" apenas a omissão de P reduziu a produtividade. Para essa cultivar o incremento de P e K aumentou a produtividade. A cultivar "Nayarit", mais produtiva que "Juliana", absorveu maiores quantidades de N, P e K. As eficiências de recuperação desses nutrientes por ambas cultivares de cenoura foram baixas.

Palavras-chave: Daucus carota. Fertilização. Extração.

\footnotetext{
*Corresponding author

${ }^{1}$ Received for publication in $02 / 11 / 2015$; accepted in $08 / 03 / 2016$

Paper extracted from the master dissertation of the fourth author.

${ }^{2}$ Universidade Federal de Viçosa - Campus Rio Paranaíba, Rio Paranaíba, MG, Brazil; nataliaassuncao.ufv@gmail.com, leonardo.aquino@ufv.br, luizsantos.ufv@gmail.com.

${ }^{3}$ Faculdade do Noroeste de Minas, Patos de Minas, MG, Brazil; junia.clemente@gmail.com.

${ }^{4}$ Instituto de Pesquisa Agrícola do Cerrado, Rio Paranaíba, MG, Brazil; lucieldezordi@gmail.com.
} 


\section{INTRODUCTION}

Carrot (Daucus carota L.) is among the ten most economically important vegetable in the world. The yield potential of this crop is 100 to $120 \mathrm{Mg}^{-}$ 1 , however, the Brazilian average yield is very low, around $33 \mathrm{Mg} \mathrm{ha}^{-1}$ (EMBRAPA HORTALIÇAS, 2014).

Fertilization has significant importance in production costs and directly influences the carrot root production and quality (LUZ et al., 2009b). High doses of fertilizers are often applied aiming to increase its root size and yield, and improve its appearance to reach a good market price (BRUNO et al., 2007)

The decreasing order of macronutrients extracted by carrot crops is usually: $\mathrm{K}, \mathrm{N}, \mathrm{Ca}, \mathrm{P}, \mathrm{S}$ and $\mathrm{Mg}$ (CECILIO FILHO; PEIXOTO, 2013). The quantitative values of $\mathrm{N}, \mathrm{P}$ and $\mathrm{K}$ is very important (LUZ et al., 2009b). $\mathrm{P}$ is applied at larger quantities because of this nutrient loss due to its strong adsorption to iron and aluminum oxides (MOREIRA et al., 2006). Potassium and $\mathrm{N}$ are absorbed by carrot in quantities larger than other nutrients (CECILIO FILHO; PEIXOTO, 2013) and fertilization with these nutrients is usually performed as split topdressings. Thus, possible salinity effects in the crop initial stage and losses are minimized.

Most low yields are related to problems of inadequate fertilization, either by under or over fertilization. Producers usually exceed official recommendations from researches and extension programs, since these recommendations aim lower yields than those obtained by them. Moreover, the expected yield, nutrient content in the soil, buffering capacity of the soil and plant efficiency in absorb nutrients should be considered to establish the adequate nutrient rates to be applied (OLIVEIRA et al., 2005).

The balance between the amount of nutrients that the soil is able to supply and the plant requirement to reach a certain yield should be considered for fertilizing as a rational method to optimize fertilizations. This method has consistent theoretical basis, which allows recommendations to be broader, without regionalist restrictions, and able to continuous improvement (OLIVEIRA et al., 2005; SANTOS et al., 2008). The link between the nutrient quantity to be applied and quantity required by the crop, in a nutrient balance system, is based on the crop nutrient recovery efficiency.

The nutrient recovery efficiency is the nutrient rate absorbed by the plant from the fertilizer applied, which is calculated by the ratio between the nutrient content of a fertilized and an unfertilized plant and the amount of the nutrient applied via fertilization (FAGERIA, 1998). In general, this ratio indicates the percentage of the nutrient applied that is absorbed by the plant.

Several factors influence the nutrient absorption efficiency and consequently, the crop yield (FAGERIA, 1998), such as precipitation, temperature, solar radiation, soil $\mathrm{pH}$, soil organic matter content, salinity, aluminum toxicity, phosphorus deficiency, genetic variability, root growth, mycorrhizae, allelopathy, diseases, pests and weeds.

Adjustments on fertilizer recommendation for carrot crops are possible from data on the plant efficiency in recovering nutrients and the carrot nutrient requirements. Therefore, the objective of this work was to evaluate the carrot crop recovery efficiency of nitrogen, phosphorus and potassium from fertilizers.

\section{MATERIAL AND METHODS}

The experiments were conducted in 2013, in an experimental area in Rio Paranaiba, State of Minas Gerais, Brazil $\left(19^{\circ} 12^{\prime} 21^{\prime \prime S}, 46^{\circ} 10^{\prime} 05^{\prime \prime} \mathrm{W}\right.$ and $1,140 \mathrm{~m}$ of altitude). The climate is Aw, tropical with dry season, according to the classification of Koppen, and the soil was classified as Red-Yellow Latossol of very clayey texture. Soil chemical characteristics at the beginning of the experiment are shown in Table 1.

Two field experiments were conducted using summer and winter cultivars. The summer cultivar Juliana was sown on February 26, 2013 and harvested on June 08, 2013; and the winter cultivar Nayarit was sown on August 02, 2013 and harvested on December 07, 2013. The carrot crops were sown in succession to maize, whose residues were cut mechanically in both experiments, with soil preparation performed with three harrowings and one plowing, and two passes of a bed forming machine.

Table 1. Chemical characterization of the soil at 0-30 $\mathrm{cm}$ depth.

\begin{tabular}{|c|c|c|c|c|c|c|c|c|c|c|c|c|c|c|}
\hline Cultivars & $\begin{array}{c}\mathrm{pH} \\
\left(\mathrm{CaCl}_{2}\right)\end{array}$ & $\begin{array}{c}\mathrm{P} \\
\mathrm{mg} \mathrm{dm}\end{array}$ & $\begin{array}{c}\text { OM } \\
\%\end{array}$ & $\mathrm{~K}^{+}$ & $\mathrm{Ca}^{2+}$ & $\begin{array}{l}\mathrm{Mg}^{2+} \\
---\mathrm{mm}\end{array}$ & $\begin{array}{l}\text { CEC } \\
\mathrm{dm}^{-3}\end{array}$ & $\mathrm{H}+\mathrm{Al}$ & $\mathrm{Al}^{3+}$ & B & $\begin{array}{c}\mathrm{Cu} \\
--\mathrm{r}\end{array}$ & $\begin{array}{l}\mathrm{Fe} \\
\mathrm{g} d \mathrm{dm}\end{array}$ & Mn & $\mathrm{Zn}$ \\
\hline Juliana & 5.8 & 128 & 3.2 & 2.5 & 43 & 17 & 62.5 & 27 & 0 & 0.41 & 3.1 & 67 & 3.4 & 10 \\
\hline Nayarit & 5.6 & 124 & 3.3 & 3.4 & 33 & 13 & 83.2 & 33.8 & 0 & 0.37 & 3.9 & 51 & 3.1 & 7.2 \\
\hline
\end{tabular}

Extractors: P - Resin; K - Mehlich - 1; Ca, Mg and Al - KCl 1 mol L-1 ; B - hot water; Cu, Fe, Mn and Zn - DTPA pH 7.3. 
In both experiments, the treatments consisted of six fertilization combinations of $\mathrm{N}, \mathrm{P}_{2} \mathrm{O}, \mathrm{K}_{2} \mathrm{O}(\mathrm{kg}$ $\left.\mathrm{ha}^{-1}\right)$ : fertilization without $\mathrm{N}(0-500-450)$, without $\mathrm{P}$ (100-0-450), without K (100-500-0), standard (100$500-450)$, higher than standard (100-700-600) and lower than standard (100-300-300); and randomized block experimental designs were used with four replications.

Half of the $\mathrm{N}$ and $30 \%$ of the $\mathrm{K}$ were applied at sowing. The remainder was applied in two equal topdressings at 38 and 54 days after sowing. $\mathrm{P}$ was integrally applied at sowing.

Each plot consisted of an $8 \mathrm{~m}$ bed, spaced $1.75 \mathrm{~m}$ from center to center of adjacent beds, i.e., each plot was $14 \mathrm{~m}^{2}$. The plants were arranged in four double rows in each bed. The evaluated area was the 3 center meters of each plot.

In both experiments, sowing fertilizer distribution was performed manually and the fertilizer was incorporated with the bed forming machine. The seeds were sown directly to the beds, with density equivalent to 1.7 million seeds per hectare. A thinning was performed After emergence to adjust the population to 600,000 plants per hectare. Other cultural practices, such as irrigation, and weed, pest and disease control, were performed according to the practices adopted by farmers in the Alto Paranaiba region.

The harvest was carried out when most of the roots had Class 22, the most accepted commercial standard, which requires roots with length of 22 to $26 \mathrm{~cm}$, diameter less than $1 \mathrm{~cm}$ and absence of pests, disease symptoms or green shoulder and cracks (CEAGESP, 2014). The roots and shoots produced were weighed after harvest. Sub-samples of roots and shoots of carrots were evaluate for nutrient content.

The samples were washed in water, rinsed in deionized water, dried in a forced air circulation oven at $70^{\circ} \mathrm{C}$ for $72 \mathrm{~h}$, ground in a Wiley mill and evaluated for $\mathrm{N}, \mathrm{P}$ and $\mathrm{K}$ contents according to methods described by Malavolta et al. (1997). The content of these nutrients in the plants was evaluated by multiplying the nutrient content found in the dry matter $\left(\mathrm{g} \mathrm{g}^{-1}\right)$ by the dry weight $(\mathrm{g})$ of the plants in the plot. The carrot recovery efficiency of $\mathrm{N}, \mathrm{P}$ and $\mathrm{K}$ were calculated for the standard rate (100:500:450 $\mathrm{kg} \mathrm{ha}{ }^{-1}$ of $\mathrm{N}: \mathrm{P}_{2} \mathrm{O}_{5}: \mathrm{K}_{2} \mathrm{O}$ ), according to the following equation:

$x 100$

$\operatorname{er} \mathrm{Nu}_{\mathrm{i}}=\left[\left(\operatorname{extp} a \mathrm{Nu}_{\mathrm{i}}-\operatorname{extpn} a \mathrm{Nu}_{\mathrm{i}}\right) / \operatorname{dos} a p l \mathrm{Nu}_{\mathrm{i}}\right]$

were:

er $\mathrm{Nu}_{\mathrm{i}}$ : nutrient recovery efficiency $(\%)$;

extpa $\mathrm{Nu}_{\mathrm{i}}$ : nutrient extraction by the plants fertilized with the nutrient $\left(\mathrm{kg} \mathrm{ha}^{-1}\right)$;

extpna $\mathrm{Nu}_{\mathrm{i}}$ : nutrient extraction by plants not fertilized with the nutrient $\left(\mathrm{kg} \mathrm{ha}^{-1}\right)$; $\left(\mathrm{kg} \mathrm{ha}^{-1}\right)$.

dosapl $\mathrm{Nu}_{\mathrm{i}}$ : rate of the nutrient applied

Data were subjected to analysis of variance and means compared by Dunnett test at $5 \%$, comparing the fertilizations without $\mathrm{N}$, without $\mathrm{P}$ without K, higher than standard, lower than standard, and standard (usually used by farmers). The software Assistat was used for statistical analysis.

\section{RESULTS AND DISCUSSION}

The soils of both experiments had high fertility, which are needed to the carrot crops, which require large amount of nutrients, thus justifying the assessment on recovery efficiency in these soils.

The fertilization influenced the commercial yield of both cultivars. The commercial yield of the cultivar Juliana, with fertilizations higher and lower than the standard (100:700:600 and 100:300:300 kg $\mathrm{ha}^{-1}$ of $\mathrm{N}: \mathrm{P}_{2} \mathrm{O}_{5}: \mathrm{K}_{2} \mathrm{O}$, respectively), was not different than the yield with standard fertilization (100:500:450 kg ha ${ }^{-1}$ of $\mathrm{N}: \mathrm{P}_{2} \mathrm{O}_{5}: \mathrm{K}_{2} \mathrm{O}$ ). This result indicates that the known standard fertilization for this cultivar can be reduced without compromising the yield. The lack of fertilization of N, P or K reduced the crop yield (Table 2 ).

The cultivar Nayarit had higher yield with fertilization higher than standard and lower yield with without $\mathrm{P}$ fertilization (100:0:450 kg ha-1 of $\left.\mathrm{N}: \mathrm{P}_{2} \mathrm{O}_{5}: \mathrm{K}_{2} \mathrm{O}\right)$, compared to plants with standard fertilization (100-500-450). The dry leaf weight was significantly lower with standard fertilization, showing that the response to fertilization depends on the productive potential, which is influenced by the planting time and cultivar. The cultivar Nayarit had greater rate of photoassimilates in the roots compared to the leaves, increasing the harvest index (Table 2).

The Nayarit, which had crop conditions typical of winter (considered favorable), had higher yield compared to the cultivar Juliana, which were cropped in typical summer conditions. Oliveira et al. (2008) and Luz et al. (2009a) attributed the carrot greatest yield in winter to the lower incidence of leaf diseases and longer cycle in this season. Moreover, lower temperatures reduce leaf senescence time, allowing a longer duration of the active leaf area and thus, a greater crop yield. Higher yields require greater absorption of nutrients, which explains the best response to the increase in $\mathrm{P}$ and $\mathrm{K}$ of the cultivar Nayarit compared to the Juliana.

Root dry matter production of the cultivar Juliana and Nayarit increased with NP and P fertilization, respectively, compared to the standard fertilization (Table 2). Hussain et al. (2008) stated that the dry matter production of carrot is related to temperature changes. They simulated small temperature increases and found higher increases in plant dry matter compared to the root dry matter, i.e., a reduction in the harvest index, which explains the greater photoassimilate rates in roots of winter cultivars.

Rev. Caatinga, Mossoró, v. 29, n. 4, p. 859 - 865, out. - dez., 2016 
The N, P and K average contents were overall higher in the cultivar Nayarit, except for the $\mathrm{N}$ content in the leaf (Table 3). This result can be explained by the crop 128-day cycle compared to the 103-day cycle of the cultivar Juliana. Furthermore, the winter crop had greater absorption of nutrients.
Regarding efficient management of fertilizers, data on root and leaf productivity and nutrient content are used to assess the extraction and export of nutrients, which assists in recommendations to achieve higher productivities (OLIVEIRA et al., 2005; SANTOS et al., 2008).

Table 2. Yield of commercial roots, dry matter of roots and leaves for the fertilizations without N, without $\mathrm{P}$, without $\mathrm{K}$, higher or lower than the standard, in two carrot cultivars.

\begin{tabular}{|c|c|c|c|}
\hline & Productivity $\left(\mathrm{t} \mathrm{ha}^{-1}\right)$ & Dry matter of roots $\left(\mathrm{t} \mathrm{ha}^{-1}\right)$ & Dry matter of leaves $\left(\mathrm{t} \mathrm{ha}^{-1}\right)$ \\
\hline & \multicolumn{3}{|c|}{ Cultivar 'Juliana' (summer) } \\
\hline $0-500-450$ & $53.4 *$ & $3.29 *$ & $1.62 *$ \\
\hline $100-0-450$ & $54.0 *$ & $3.26 *$ & 2.14 \\
\hline $100-500-0$ & $54.6 *$ & 4.59 & 1.88 \\
\hline $100-500-450$ & 66.1 & 4.57 & 2.15 \\
\hline $100-700-600$ & 67.8 & 4.63 & $2.70 *$ \\
\hline $100-300-300$ & 58.5 & 4.42 & 1.93 \\
\hline Average & 59.1 & 4.12 & 2.07 \\
\hline \multirow{2}{*}{$\mathrm{CV}(\%)$} & 6.80 & 10.49 & 10.10 \\
\hline & \multicolumn{3}{|c|}{ Cultivar 'Nayarit' (winter) } \\
\hline $0-500-450$ & 65.1 & 6.58 & 2.39 \\
\hline $100-0-450$ & $58.3 *$ & $5.89 *$ & $2.89 *$ \\
\hline $100-500-0$ & 72.3 & 7.08 & $3.16 *$ \\
\hline $100-500-450$ & 67.1 & 7.13 & 2.38 \\
\hline $100-700-600$ & $78.2 *$ & 7.89 & $3.34 *$ \\
\hline $100-300-300$ & 74.0 & 7.48 & $2.84 *$ \\
\hline Average & 69.2 & 7.00 & 2.83 \\
\hline $\mathrm{CV}(\%)$ & 5.34 & 6.18 & 7.93 \\
\hline
\end{tabular}

Averages followed by the symbol $(*)$ differ from the standard $\left(100: 500: 450 \mathrm{~kg} \mathrm{ha}^{-1}\right.$ of $\left.\mathrm{N}: \mathrm{P}_{2} \mathrm{O}_{5}: \mathrm{K}_{2} \mathrm{O}\right)$ at $5 \%$ probability by Dunnett's test.

The treatment without P (100-0-450) of both cultivars had low yield, which can be attributed to the slower plant growth, especially the roots, which had smaller volume.

Low growth can cause $\mathrm{N}$ concentration, thus no difference in $\mathrm{N}$ foliar content in the treatment without $\mathrm{P}$ was found compared to the standard fertilization with the cultivar Juliana. This effect was also found with the cultivar Nayarit, since the $\mathrm{N}$ content in the roots of plants without $\mathrm{P}$ was similar to the standard fertilization (Table 3). Moreover, this effect may be related to the longer time that the cultivar Nayarit remained in the field. The adequate rates of $\mathrm{N}$ and $\mathrm{P}$ promoted increases in crop production, greater than those found with the use of each nutrient singly, confirming the results of Alves et al. (1999).

The fertilizations without $\mathrm{P}$ and without $\mathrm{K}$ for the cultivar Juliana statistically differed from the standard fertilization only in $\mathrm{K}$ content of roots, due to the high mobility of $\mathrm{K}$ in the plant and the carrot high requirements of $\mathrm{K}$. The $\mathrm{N}$ content in roots of plants of cultivar Nayarit that had no $\mathrm{N}$ fertilization, and the $\mathrm{P}$ content in roots of plants without $\mathrm{P}$ fertilization were lower than the standard fertilization, due exclusively to the lack of such nutrients (Table 3 ).

The fertilizations without $\mathrm{N}$, without $\mathrm{P}$ and without $\mathrm{K}$ of the cultivar Juliana had extraction and export values statistically lower than the standard fertilization. The N, P and $\mathrm{K}$ extraction values with fertilization higher than standard were higher than the values of the standard fertilization for both varieties. The increase in fertilization rates contributed to increase yield and nutrient content in leaves and roots, resulting in higher extraction of nutrients by the carrot (Table 4).

The $\mathrm{N}$ extracted by the cultivar Juliana with standard and higher than standard fertilizations, and the $\mathrm{N}$ and $\mathrm{K}$ extracted by the cultivar Nayarit, exceeded the amounts applied, regardless of the fertilization rate (Table 4). The soil nutrients contributed to the yield achieved, otherwise the nutrients available would limit the yield. Therefore, the total quantities extracted (roots and leaves) and exported (roots) should be considered for a balanced nutritional system. Thus, minimizing the effect of nutrient limitation on the expected yield requires to meet the nutrient absorption by plant, while ensuring the maintenance of soil fertility requires application of at least the amount of the nutrients exported (SHARMA et al., 2012). 
N. S. ASSUNÇÃO et al.

Table 3. Contents of nitrogen $(\mathrm{N})$, phosphorus $(\mathrm{P})$ and potassium $(\mathrm{K})$ in roots and leaves of the plants with fertilizations without $\mathrm{N}$, without $\mathrm{P}$, without $\mathrm{K}$, standard, higher and lower than the standard, in two carrot cultivars.

\begin{tabular}{|c|c|c|c|c|c|c|}
\hline \multirow{2}{*}{$\begin{array}{c}\mathrm{N}-\mathrm{P}_{2} \mathrm{O}_{5}-\mathrm{K}_{2} \mathrm{O}(\mathrm{kg} \\
\left.\mathrm{ha}^{-1}\right)\end{array}$} & $\mathrm{N}$ & $\mathrm{P}$ & $\mathrm{K}$ & $\mathrm{N}$ & $\mathrm{P}$ & $\mathrm{K}$ \\
\hline & \multicolumn{3}{|c|}{ Content in roots $\left(\mathrm{g} \mathrm{kg}^{-1}\right)$} & \multicolumn{3}{|c|}{ Content in leaves $\left(\mathrm{g} \mathrm{kg}^{-1}\right)$} \\
\hline & \multicolumn{6}{|c|}{ Cultivar 'Juliana' (summer) } \\
\hline $0-500-450$ & 10.6 & 4.4 & 52.1 & 25.2 & $2.3 *$ & $60.3 *$ \\
\hline $100-0-450$ & 12.6 & 4.0 & $55.5 *$ & 25.1 & 2.1 & 62.8 \\
\hline $100-500-0$ & 11.2 & 3.3 & $34.5 *$ & $23.1 *$ & 2.1 & $49.6 *$ \\
\hline $100-500-450$ & 11.2 & 3.9 & 45.3 & 26.4 & 1.9 & 66.4 \\
\hline $100-700-600$ & 12.0 & 3.0 & 44.5 & $21.6 *$ & 2.1 & 64.6 \\
\hline $100-300-300$ & 11.2 & 3.6 & 44.8 & 26.2 & 1.9 & 64.9 \\
\hline Average & 11.5 & 3.7 & 46.1 & 24.6 & 2.1 & 61.4 \\
\hline \multirow[t]{2}{*}{ CV $(\%)$} & 10.35 & 13.46 & 8.37 & 3.81 & 10.17 & 4.03 \\
\hline & \multicolumn{6}{|c|}{ Cultivar 'Nayarit' (winter) } \\
\hline $0-500-450$ & $12.7 *$ & 5.1 & 65.6 & 19.8 & 3.1 & 74.6 \\
\hline $100-0-450$ & 13.5 & $4.1 *$ & 68.7 & 20.0 & 2.7 & 75.3 \\
\hline $100-500-0$ & 16.0 & 5.0 & 59.1 & 21.7 & 2.7 & 71.2 \\
\hline $100-500-450$ & 15.2 & 5.3 & 66.8 & 22.2 & 3.2 & 72.7 \\
\hline $100-700-600$ & 15.9 & 5.2 & 70.5 & 22.0 & 3.0 & 75.9 \\
\hline $100-300-300$ & 16.7 & 5.6 & 69.1 & 21.7 & 3.0 & 75.3 \\
\hline Average & 15.0 & 5.0 & 66.6 & 21.2 & 3.0 & 74.2 \\
\hline CV $(\%)$ & 5.55 & 7.78 & 6.81 & 6.24 & 11.35 & 4.02 \\
\hline
\end{tabular}

Averages followed by the symbol $(*)$ differ from the standard $\left(100: 500: 450 \mathrm{~kg}^{-1}\right.$ of $\left.\mathrm{N}: \mathrm{P}_{2} \mathrm{O}_{5}: \mathrm{K}_{2} \mathrm{O}\right)$ at $5 \%$ probability by Dunnett`s test.

Fertilization without $\mathrm{N}$ had low $\mathrm{P}$ extractions, while fertilization without $\mathrm{P}$ had low $\mathrm{N}$ extractions (Table 4) due to the synergistic effect between $\mathrm{N}$ and P. Alves et al. (1999) found increased absorption of $\mathrm{N}$ and $\mathrm{P}$ in maize by supplying both nutrients. Smolen and Wlodzimierz (2009) found high carrot yields applying high rates of $\mathrm{N}$, due to the larger size of the roots and photosynthetic surface reached. Moreover, appropriate nitrogen fertilizations in carrot crops result in carrots with better quality by increasing their sugar (ALI et al., 2003) and carotenoid contents (CHENARD et al., 2005;
RAKOCEVIC et al., 2012).

Among the nutrients evaluated, $\mathrm{K}$ is the most extracted and exported by carrot. $\mathrm{K}$ is related to product quality by its role on the activation of several enzymes during biosynthesis of photoassimilates, carbohydrate transport from the source (leaf) to reservoirs (roots), activate enzymes for starch synthase, and its significant influence on carotene contents in the root (ALI et al., 2003). However, excess of $\mathrm{N}$ and $\mathrm{K}$ significantly influence the incidence of root cracking (ALI et al., 2003).

Table 4. Extraction and export of nitrogen $(\mathrm{N}), \mathrm{P}_{2} \mathrm{O}_{5}$ and $\mathrm{K}_{2} \mathrm{O}$, with fertilizations without $\mathrm{N}$, without $\mathrm{P}$, without $\mathrm{K}$, standard, higher and lower than the standard, in two carrot cultivars.

\begin{tabular}{|c|c|c|c|c|c|c|}
\hline \multirow{2}{*}{$\begin{array}{c}\mathrm{N}-\mathrm{P}_{2} \mathrm{O}_{5}-\mathrm{K}_{2} \mathrm{O}(\mathrm{kg} \\
\left.\mathrm{ha}^{-1}\right)\end{array}$} & $\mathrm{N}$ & $\mathrm{P}_{2} \mathrm{O}_{5}$ & $\mathrm{~K}_{2} \mathrm{O}$ & $\mathrm{N}$ & $\mathrm{P}_{2} \mathrm{O}_{5}$ & $\mathrm{~K}_{2} \mathrm{O}$ \\
\hline & \multicolumn{3}{|c|}{ Extraction $\left(\mathrm{kg} \mathrm{ha}^{-1}\right)$} & \multicolumn{3}{|c|}{ Export $\left(\mathrm{kg} \mathrm{ha}^{-1}\right)$} \\
\hline & \multicolumn{6}{|c|}{ Cultivar 'Juliana' (summer) } \\
\hline $0-500-450$ & $73.8 *$ & $40.6 *$ & $318.0 *$ & $35.2 *$ & $31.9 *$ & $201.2 *$ \\
\hline $100-0-450$ & $96.7 *$ & $38.2 *$ & $382.5 *$ & $42.9 *$ & $29.1 *$ & $209.1 *$ \\
\hline $100-500-0$ & $96.3 *$ & $42.2 *$ & $310.1 *$ & 51.8 & $33.3 *$ & $196.4 *$ \\
\hline $100-500-450$ & 104.7 & 49.9 & 407.3 & 49.2 & 41.9 & 240.7 \\
\hline $100-700-600$ & $109.4 *$ & $41.4 *$ & $435.7 *$ & $55.8 *$ & $29.7 *$ & 239.2 \\
\hline $100-300-300$ & 99.9 & $42.2 *$ & 390.6 & 48.4 & $34.1 *$ & 240.7 \\
\hline Average & 96.8 & 42.4 & 374.1 & 47.2 & 33.3 & 221.3 \\
\hline \multirow[t]{2}{*}{ CV $(\%)$} & 2.51 & 7.62 & 2.85 & 2.98 & 9.84 & 5.37 \\
\hline & \multicolumn{6}{|c|}{ Cultivar 'Nayarit' (winter) } \\
\hline $0-500-450$ & $138.2 *$ & 96.1 & $739.4 *$ & 87.6 & 80.8 & 541.0 \\
\hline $100-0-450$ & $135.4 *$ & $73.3 *$ & $741.8 *$ & 76.6 & $52.1 *$ & 511.2 \\
\hline $100-500-0$ & $175.2 *$ & 105.4 & 760.0 & 116.7 & 83.1 & 522.0 \\
\hline $100-500-450$ & 153.0 & 101.4 & 778.2 & 107.6 & 83.3 & 553.6 \\
\hline $100-700-600$ & $199.7 *$ & $111.3 *$ & $949.4 *$ & $122.1 *$ & 90.5 & $650.6 *$ \\
\hline $100-300-300$ & $189.3 *$ & $117.5 *$ & $883.5 *$ & $123.0 *$ & $95.9 *$ & 598.0 \\
\hline Average & 165.2 & 100.8 & 807.1 & 105.6 & 81.0 & 585.3 \\
\hline CV $(\%)$ & 2.06 & 3.05 & 1.81 & 5.15 & 4.86 & 5.93 \\
\hline
\end{tabular}

Averages followed by the symbol (*) differ from the standard $\left(100: 500: 450 \mathrm{~kg} \mathrm{ha}^{-1}\right.$ of $\left.\mathrm{N}_{2} \mathrm{P}_{2} \mathrm{O}_{5}: \mathrm{K}_{2} \mathrm{O}\right)$ at $5 \%$ probability by Dunnett's test. 
The recovery efficiency values were calculated based on the standard fertilization. The cultivar Juliana had recovery efficiency averages of $30.9 \%(\mathrm{~N}), 2.33 \%(\mathrm{P})$ and $21.59 \%(\mathrm{~K})$, while the cultivar Nayarit had recovery efficiency averages of $14.79 \%(\mathrm{~N}), 5.61 \%(\mathrm{P})$ and $4.04 \%(\mathrm{~K})$ (Table 5). The cultivar Juliana had greater recovery of $\mathrm{N}$ and $\mathrm{K}$ compared to the Nayarit, which can be attributed to the greater rate of dry matter and nitrogen, and the lower availability of $\mathrm{K}$ in the soil of the cultivar Juliana (Table 1). The cultivar Nayarit had longer crop cycle and greater yield compared to the Juliana, which explains the higher recovery of $\mathrm{P} . \mathrm{P}$ is preferentially allocated to roots and thus yield increases are associated with high recovery rates of P. Both cultivars had low recovery efficiency rates, confirming that the recovery of nutrients by crops efficiency is, in general, very low (Fageria, 1998)

The absorption-related characteristics of cultivars, such as the Michaelis-Menten $(\mathrm{km})$ and minimum concentration $\left(\mathrm{C}_{\min }\right)$, can influence the recovery efficiency. For example, absorption-related variables of potato differ between cultivars and interfere in the absorption of phosphorus (FERNANDES, 2013).

The estimated overall efficiency of fertilizers is equal to or less than $50 \%$ for $\mathrm{N}$, less than $10 \%$ for phosphorus and about $40 \%$ for K (BALIGAR et al., 2001). Fageria (2000) and Fageria (1997) found recovery efficiency of $\mathrm{K}$ of $66 \%, \mathrm{P}$ of $45 \%$ and $\mathrm{N}$ of $15 \%$, in upland rice crops in the Cerrado biome. According to Rambo et al. (2007), the estimated global efficiency of $\mathrm{N}$ in grain crops is only $33 \%$, and alternatives to increase its efficiency are very discussed, for example, the adoption of better management practices such as the use of appropriate application rates and time.

Table 5. Recovery efficiency of nitrogen $(\mathrm{N})$, phosphorus $(\mathrm{P})$ and potassium, with the standard fertilization (100:500:450 $\mathrm{kg} \mathrm{ha}{ }^{-1} \mathrm{~N}: \mathrm{P}_{2} \mathrm{O}_{5}: \mathrm{K}_{2} \mathrm{O}$ ), in two carrot cultivars.

\begin{tabular}{lccc}
\hline \multirow{2}{*}{ Cultivar } & $\mathrm{N}$ & $\mathrm{P}$ & $\mathrm{K}$ \\
\cline { 2 - 4 } & \multicolumn{2}{c}{ Average \pm standard deviation of the recovery efficiency $(\%)$} \\
\hline Juliana & $30.90 \pm 0.797$ & $2.33 \pm 0.176$ & $21.59 \pm 1.933$ \\
Nayarit & $14.79 \pm 4.172$ & $5.61 \pm 0.445$ & $4.04 \pm 1.984$ \\
\hline
\end{tabular}

The $\mathrm{P}$ recovery efficiency of the cultivars Juliana $(2: 33 \%)$ and Nayarit $(5,61 \%)$ (Table 5) were considered low compared to $\mathrm{N}$ and $\mathrm{K}$. These nutrients are more accumulated compared to $\mathrm{P}$ and its loss is less obvious, which may explain this difference.

In tropical soils, $\mathrm{P}$ can form stable bonds with iron and aluminum oxy-hydroxides, which reduce its availability (and recovery) for plants (VILAR et al., 2010). Both experiments had high availability of $P$, therefore, the nutrients in the soil supplied part of the plant's requirement, and a smaller portion came from the fertilizers applied, which also explains the lower recovery of the $\mathrm{P}$ applied.

\section{CONCLUSION}

Carrot recovery efficiency of nitrogen, phosphorus and potassium is low and dependent on the growing season and cultivar used.

The lack of fertilization with nitrogen, phosphorus or potassium in the summer crop (cultivar Juliana) and phosphorus in the winter crop (cultivar Nayarit) reduces yield.

Phosphorus and potassium fertilization can be reduced in summer crops without yield loss; and an increase in phosphorus and potassium fertilization may increase yield in winter crops.

\section{ACKNOWLEDGEMENT}

À COOPADAP, FAPEMIG e CNPq pelos recursos financeiros, À CAPES pelas bolsas de mestrado concedida ao quarto e quinta autor e, à FUNARBE - Fundação Arthur Bernardes pela bolsa de produtividade em pesquisa de excelência concedida ao terceiro autor.

\section{REFERENCES}

ALI, M. D. A. et al. Effect of nitrogen and potassium on yield and quality of carrot. Pakistan Journal of Biological Sciences, Faisalabad, v. 6, n. 18, p. 1574-1577, 2003.

ALVES, V. M. C. et al. Acúmulo de nitrogênio e de fósforo em plantas de milho afetadas pelo suprimento parcial de fósforo às raízes. Revista Brasileira de Ciência do Solo, Viçosa, v. 23, n. 2, p. 299-305, 1999.

BALIGAR, V. C.; FAGERIA, N. K.; HE, Z. L Nutrient use efficiency in plants. Communications in soil science and plant analysis, New York, v. 32, n. 7-8, p. 921-950, 2001.

BRUNO, R. L. A. et al. Produção e qualidade de sementes e raízes de cenoura cultivada em solo com 
adubação orgânica e mineral. Horticultura Brasileira, Brasília, v. 25, n. 2, p. 170-174, 2007.

CEAGESP. Companhia de Entrepostos e Armazéns Gerais de São Paulo. Classificação de cenoura. Disponível em: <http://ceagesp. gov.br/produtor/ classific/fc_cenoura>. Acesso em: 25 set. 2014.

CECILIO FILHO, A. B.; PEIXOTO, F. C. Acúmulo e exportação de nutrientes em cenoura 'Forto'. Revista Caatinga, Mossoró, v. 26, n. 1, p. 64-70, 2013.

CHENARD, C. H.; KOPSELL, D. A.; KOPSELL, D. E. Nitrogen concentration affects nutrient and carotenoid accumulation in parsley. Journal of Plant Nutrition, London, v. 28, n. 2, p. 285-297, 2005.

EMBRAPA HORTALIÇAS. Empresa Brasileira de Pesquisa Agropecuária. Sistema de produção. Disponível em: <http://cnph.embrapa.br/paginas/ sistemas_producao/cultivo_da_cenoura.htm $>$.

Acesso em: 25 set. 2014

FAGERIA, N. K. Otimização da eficiência nutricional na produção das culturas. Revista Brasileira de Engenharia Agrícola e Ambiental, Campina Grande, v. 2, n. 1, p. 6-16, 1998.

FAGERIA, N. K.; BALIGAR, V. C.; JONES, C. A. Growth and mineral nutrition of field crops. 2. ed. New York, NY: MARCEL DEKKER, 1997. 624 p.

FAGERIA, N. K. Eficiência do uso de potássio pelos genótipos de arroz de terras altas. Pesquisa Agropecuária Brasileira, Brasília, v. 35, n. 10, p. $2115-2120,2000$.

FERNANDES, A. M. Adubação fosfatada em cultivares de batata (Solanum tuberosum L.). 2013. 145 f. Tese (Doutorado em Agronomia/ Agricultura: Área de concentração em Fitotecnia) Faculdade de Ciências Agronômica da UNESP, Botucatu, 2013

HUSSAIN, S. I.; HADLEY, P.; PEARSON, S. A validated mechanistic model of carrot (Daucus carota L.) growth. Scientia Horticulturae, Amsterdam, v. 117, n. 1, p. 26-31, 2008.

LUZ, J. M. Q. et al. Desempenho de cultivares de cenoura no verão e outono-inverno em Uberlândia-MG. Horticultura Brasileira, Brasília, v. 27, n. 1, p. 96-99, 2009a.

LUZ, J. M. Q. et al. Adubação de cobertura com nitrogênio, potássio e cálcio na produção comercial de cenoura. Horticultura Brasileira, Brasília, v. 27, n. 4 , p. $543-548,2009$ b.
MALAVOLTA, E.; VITTI, G. C.; OLIVEIRA, S. A. Avaliação do estado nutricional das plantas: princípios e aplicações. 2. ed. Piracicaba, SP: Associação Brasileira para Pesquisa da Potassa e do Fosfato, 1997. 319 p.

MOREIRA, F. L. M. et al. Adsorção de fósforo em solos do Estado do Ceará. Revista Ciência Agronômica, Fortaleza, v. 37, n. 1, p. 7-12, 2006.

OLIVEIRA, C. D.; BRAZ, L. T.; BANZATTO, D. A. Adaptabilidade e estabilidade fenotípica de cultivares de cenoura. Horticultura Brasileira, Brasília, v. 26, n. 1, p. 88-92, 2008

OLIVEIRA, F. H. T. et al. Desenvolvimento de um sistema para recomendação de adubação para a cultura da bananeira. Revista Brasileira de Ciência do Solo, Viçosa, v. 29, n. 1, p. 131-143, 2005.

RAKOCEVIC, L. B. et al. Effect of nitrogen fertilization on carrot quality. African Journal of Agricultural Research, Lagos, v. 7, n. 18, p. $2884-2900,2012$.

RAMBO, L. et al. Monitoramento de nitrogênio na planta e no solo para predição da adubação nitrogenada em milho. Pesquisa Agropecuária Brasileira, Brasília, v. 42, n. 3, p. 407-417, 2007.

SANTOS, F. C. et al. Modelagem da recomendação de corretivos e fertilizantes para a cultura da soja. Revista Brasileira de Ciência do Solo, Viçosa, v. 32, n. 4, p. 1661-1674, 2008.

SHARMA, K. D. et al. Chemical composition, functional properties and processing of carrot - a review. Journal of Food Science Techonology, Mysore, v. 49, n. 1, p. 22-32, 2012.

SMOLÉN, S.; WLODZIMIERZ, S. The effect of various nitrogen fertilization and foliar nutrition regimes on the concentrations of nitrates, ammonium ions, dry matter and N-total in carrot (Daucus carota L.) roots. Scientia Horticulturae, Amsterdam, v. 119, n. 3, p. 219-231, 2009

VILAR, C. C. et al. Capacidade máxima de adsorção de fósforo relacionadas a formas de ferro e alumínio em solos subtropicais. Revista Brasileira de Ciência do Solo, Viçosa, v. 34, n. 4, p. 1059-1068, 2010. 